\title{
Seasonal and Geographical Variation of Laurus nobilis L. Essential Oil from Tunisia
}

\author{
H. Marzouki ${ }^{\text {a,f }}$, A. Elaissi ${ }^{\text {b }}$, A. Khaldi ${ }^{\mathrm{c}}, \mathrm{S}$. Bouzid $^{\mathrm{d}}$,D. Falconieri ${ }^{\mathrm{e}}$, B. Marongiu*,a, A. Piras ${ }^{\mathrm{a}}$ and \\ S. Porcedda ${ }^{a}$
}

\author{
${ }^{a}$ Dipartimento di Scienze Chimiche, Università degli Studi di Cagliari, Cittadella Universitaria - 09042 Monserrato \\ (CA), Italy \\ ${ }^{b}$ Laboratoire de Pharmacognosie, Université de Monastir, Monastir, Tunisia \\ ${ }^{c}$ Institut National de Recherche en Génie Rural Eaux et Forêts de Tunis, INRGREF, Tunis, Tunisia \\ ${ }^{d}$ Laboratoire de Botanique et de Biologie végétale, Université El-Manar de Tunis, Tunisia \\ ${ }^{e}$ Istituto Tecnico Industriale Statale M. Giua - Cagliari, Italy \\ ${ }^{f}$ On leave from Laboratoire de Botanique et de Biologie végétale - Université El-Manar de Tunis - Tunisia
}

\begin{abstract}
Yield and composition of the essential oil obtained by hydrodistillation from leaves of laurel coming from ten different sites in Tunisia were determined. From each locality, leaves were harvested during four different vegetative stages (October, production of seeds; January, dormancy; April, flowering; July, vegetative activity) to look for some correlation between composition and vegetative stage. All 40 essential oil samples produced similar GC profiles containing a total of 71 peaks. 60 Compounds were identified. 1,8-cineole was, in all samples, the main constituent among different compounds such as methyl eugenol, $\alpha$-terpinyl acetate, sabinene and linalool. All essential oils considered were characterized by a clear predominance of oxygenated compounds chiefly monoterpenes then phenylporpanoids and sesquiterpenes. The concentration of this class generally decreases during the period October - July; the values are in the range $67.5 \%$ $86.1 \%$. The yields of essential oil ranged between 0.65 and $2.2 \%$ by weight. With only one exception, the higher production of essential oil was obtained during the vegetative period. A seasonal variation in the yield and composition of essential oil was revealed, while geographical variability was not pronounced and no chemotypes were observed among the samples of laurel leaf oil examined.
\end{abstract}

Keywords: Laurus nobilis, essential oil, seasonal variation.

\section{INTRODUCTION}

Laurel (Laurus nobilis. L). is a very important medicinal and aromatic plant, which belongs to the Lauraceae family [1]. Leaves of this plant produce a yellow oil known for many therapeutic indications. Leaves and their essential oil increase gastric fluid secretion and work against digestive disorders such as flatulent colic [2]. Anticonvulsive and antiepileptic activities [3] of the leaf extract have been confirmed. Recently Simic et al. [4] tested the antioxidative activity of methanolic extracts of leaves, bark and fruits. The most significant activity was obtained with the bark extract. The volatile compounds of wood and bark of this species have been studied [5]. Monoterpenes (in particular 1,8cineole and eugenol) were identified as the main class consitiuent in the bark oil, whereas sesquiterpenes (dehydrocostunolide) were the most important constituents of the wood extract. Fang et al. [6] reported their results concerning the isolation of six sesquiterpene lactones from the methanol extract of dried leaves of L. nobilis, responsible for inducing

*Address correspondence to this author at the Dipartimento di Scienze Chimiche, Università degli Studi di Cagliari, Cittadella Universitaria 09042 Monserrato (CA), Italy; Fax: + 39070675 4388;

E-mail:maronb@unica.it apoptosis. The leaf essential oil of the species under investigation showed also a very strong antibacterial activity against foodborne pathogens [7]. Moreover, pharmacological activity, which includes antifungal, anti-diabetic, and antiinflammatory activities [6], have been also demonstrated. The chemical composition of the leaf essential oil, obtained from different methods of isolation, were extensively studied by many researchers [8-12]. Generally, the yield and composition of the oil varies, depending upon the origin, the collection period, and the growth stage of the plant [13]. A study on the antimicrobial activity of different species [14] indicates little variability in oils available from different sites.

This paper reports results concerning the study of the seasonal and geographical variation in yield and composition of leaf essential oil of Laurus nobilis collected from various areas in Tunisia.

Yield and composition of the essential oil obtained by hydrodistillation (HD) from leaves of laurel from 10 different sites in Tunisia (see experimental section) were determined. Moreover, from every site, leaves were harvested during four different periods of the year. We looked for some correlation between composition and vegetative stage. 
Table 1. Geographical Coordinates of Natural Stations

\begin{tabular}{|c|c|c|}
\hline Station & Longitude & Latitude \\
\hline \hline Hammamet & $10^{\circ} 36^{\prime} 41^{\prime \prime}$ & $36^{\circ} 23^{\prime} 58^{\prime}$, \\
\hline La Marsa & $10^{\circ} 20^{\prime} 01^{\prime}$, & $36^{\circ} 52^{\prime} 59^{\prime}$, \\
\hline Rades & $10^{\circ} 16^{\prime} 34^{\prime}$, & $36^{\circ} 45^{\prime} 51^{\prime}$, \\
\hline Sousse & $10^{\circ} 28^{\prime} 19^{\prime}$, & $35^{\circ} 57^{\prime} 17^{\prime}$, \\
\hline Ain Drahem & $08^{\circ} 46^{\prime} 64^{\prime}$, & $36^{\circ} 47^{\prime} 16^{\prime}$, \\
\hline Ain Elkhassa & $08^{\circ} 51^{\prime} 34^{\prime}$, & $36^{\circ} 56^{\prime} 57^{\prime}$, \\
\hline Ain Esnoussi 1 and 2 & $08^{\circ} 55^{\prime} 06^{\prime}$, & $36^{\circ} 49^{\prime} 07^{\prime}$, \\
\hline Ain Essobeh & $08^{\circ} 52^{\prime} 29^{\prime}$, & $36^{\circ} 57^{\prime} 06^{\prime}$, \\
\hline Sajnane & $09^{\circ} 14^{\prime} 05^{\prime}$, & $37^{\circ} 03^{\prime} 21^{\prime}$, \\
\hline
\end{tabular}

\section{EXPERIMENTAL}

\section{Plant Material}

Leaves of Laurus nobilis (Lauraceae) were collected randomly from 10 sites in Tunisia during four periods of the year, according to the growing stage: October 2006, production of seeds; January 2007, dormancy; April 2007, flowering; and July 2007, vegetative activity.

Sites considered may be grouped in two bioclimatic zones: sub humid (Hammamet, La Marsa, Rades, and Sousse) and humid (Ain Drahem, Ain Elkhassa, Ain Essobeh, Ain Esnoussi 1, Ain Esnoussi 2, and Sajnane). Geographical coordinates of the stations are provided in Table 1. At each site we collected from a single tree about 2 $\mathrm{kg}$ of leaves that were separated from the lignified parts and air dried in the shadow for 15 days.

Voucher specimens of each sample were deposited in the herbarium of the Faculty of Pharmacy in Monastir (Tunisia). Codes of the samples are: $\operatorname{Ham}(1-4), \operatorname{Mar}(1-4), \operatorname{Rad}(1-4)$, Sou(1-4), AD(1-4), Ain Elk(1-4), Ain Essb(1-4), Ain Ess1(1-4), Ain Ess2(1-4) and Saj(1-4), respectively.

\section{Chemicals}

Chloroform, p-cymene, 1,8-cineole, $\alpha$-terpinene, linalool, terpin-4-ol, $\alpha$-terpineol, eugenol and methyl eugenol were purchased from Sigma-Aldrich (St. Louis, MO, USA). Myrcene, limonene, bornyl acetate and caryophyllene oxide were obtained from Fluka (Buchs, Switzerland) and $\alpha$-pinene, sabinene, $\beta$-pinene, $\beta$-phellandrene, terpinolene, borneol, $\alpha$ terpinyl acetate and $\alpha$-humulene were purchased from Extrasynthese (Genay, France).

\section{Oil Isolation}

A $100 \mathrm{~g}$ amount of dried leaves boorishly crushed and mixed with $600 \mathrm{ml}$ distilled water were subjected to HD for 4h using a modified Clevenger-type apparatus described by Simard et al. [16]. Yield of essential oil, Y\%, is expressed as percentage of the mass of the essential oil with respect to the air-dried vegetable material. Three repeated distillation were performed. Yields reported in Table $\mathbf{2}$ are mean values.

\section{GC-MS Analysis}

A gas chromatograph, GC, AGILENT Technologies Inc. (Santa Clara, CA, USA) model $6890 \mathrm{~N}$ was employed for analysis of the extracts. It was equipped with a split-splitless injector, an autosampler AGILENT model 7683 and an AGILENT HP5 fused silica column; 5\% phenylmethylpolysiloxane, $30 \mathrm{~m} \times 0.25 \mathrm{~mm}$ i.d., film thickness $0.25 \mu \mathrm{m}$. GC conditions used were: programmed heating from 60 to $280^{\circ} \mathrm{C}$ at $3^{\circ} \mathrm{C} / \mathrm{min}$ followed by $30 \mathrm{~min}$ under isothermal conditions. Data were recorded after a $3 \mathrm{~min}$ lag phase. The injector was maintained at $250^{\circ} \mathrm{C}$. Helium was the carrier gas at $1.0 \mathrm{~mL} / \mathrm{min}$; the sample $(1 \mu \mathrm{L})$ was injected in the split mode $(1: 20)$. The GC was fitted with a quadrupole mass spectrometer, MS, AGILENT model 5973 detector. MS conditions were as follows: ionization energy 70 $\mathrm{eV}$, electronic impact ion source temperature $200{ }^{\circ} \mathrm{C}$, quadrupole temperature $100{ }^{\circ} \mathrm{C}$, scan rate $1.6 \mathrm{scan} / \mathrm{sec}$, mass range 50-500 u.

Software adopted to handle mass spectra and chromatograms was ChemStation. NIST02 and LIBR(TP) [15] Mass Spectra Libraries were used as references. Samples, a mix of

Table 2. Yields in Essential Oil, \% by Weight, of Natural Stations for Vegetative Stage

\begin{tabular}{|c|c|c|c|c|}
\hline Station & $\mathbf{I}$ & II & III & IV \\
\hline Hammamet & 0,9 & 0,9 & 0,8 & 1,1 \\
\hline Rades & 0,8 & 0,9 & 0,9 & 1,0 \\
\hline Sousse & 1,8 & 1,6 & 1,5 & 2,2 \\
\hline Ain Elkhassa & 0,9 & 0,8 & 1,0 & 1,2 \\
\hline Ain Esnoussi 1 & 1,2 & 1,1 & 1,2 & 1,6 \\
\hline Ain Esnoussi 2 & 1,6 & 1,5 & 1,3 & 1,3 \\
\hline
\end{tabular}


Table 3. Retention times, $t_{R}$, Kovats' indices, $I_{K}$, and chromatographic area percentages of constituents and their acronyms used for chemometric study, of laurel essential oil obtained from leaves collected in Hammamet at different vegetative stage: $I$, production of seeds; II, dormancy; III, flowering; IV, vegetative activity. Classes considered are: hydrocarbon monoterpenes, HM; oxygenated monoterpenes, OM; hydrocarbon sesquiterpenes, HS, oxygenated sesquiterpenes, OS; hydrocarbon phenylpropanoids, HPrB; oxygenated phenylpropanoids, OPrB and others, OTH. For each sample is given also the per cent yield, $Y \%$, of the oil

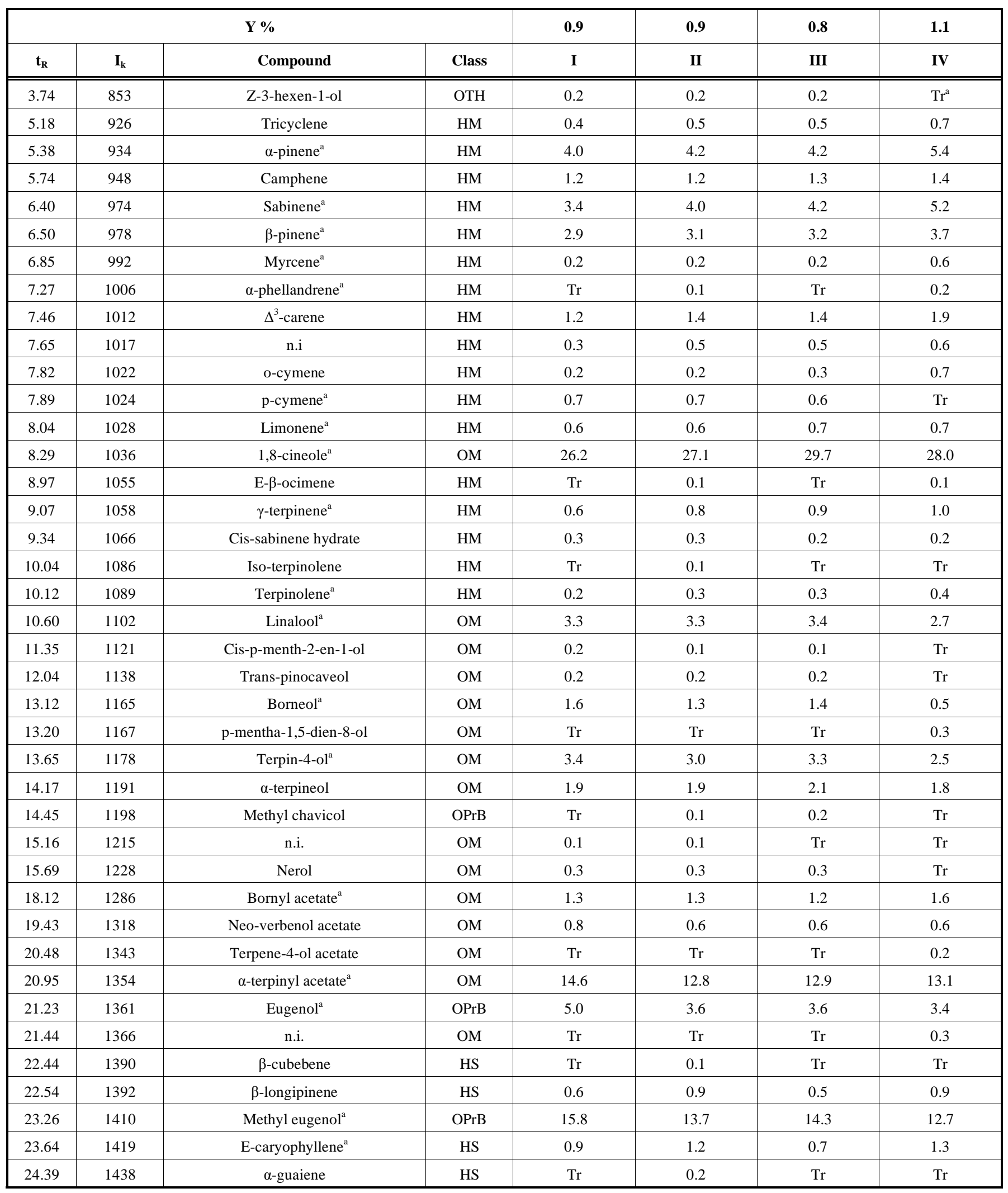


(Table 3). Contd.....

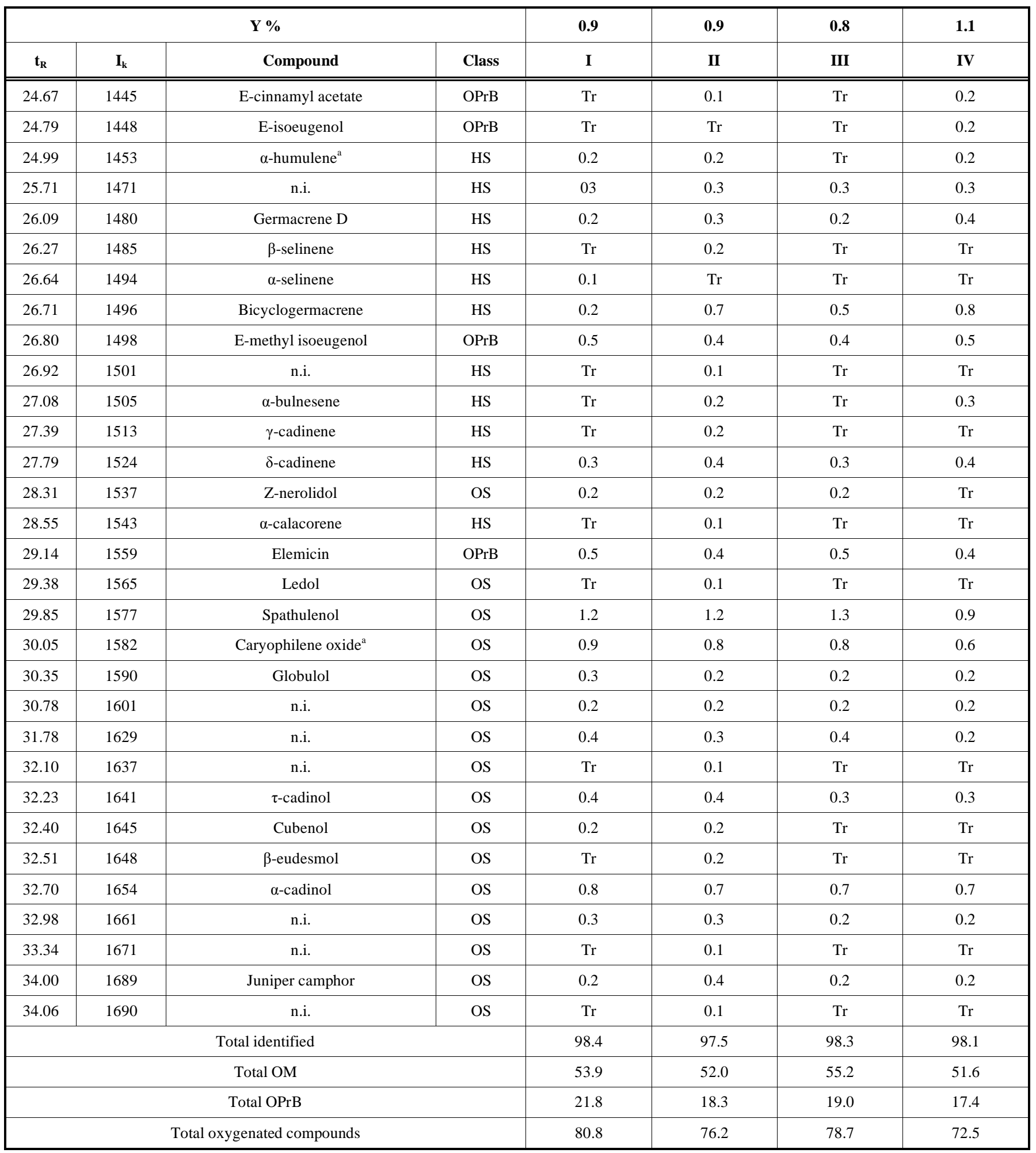

${ }^{\mathrm{a}}$ Identification confirmed by injection of authentic sample.

n.i. unidentified compound.

the oils obtained from three repeated hydrodistillations, were run in chloroform at a dilution ratio of 1:100. No repeated runs were performed.

Compounds were identified by matching their mass spectra and retention times with those reported in the literature $[16,17]$. Moreover, identification of 20 compounds, among the more important constituents, has been confirmed by injection of authentic samples (see Table 1). The chromatographic results present in Table $\mathbf{1}$ are expressed as area percentages, calculated without any response factor, as a function of retention time. The data in the tables also report the non-isothermal Kováts' retention indices, $\mathrm{I}_{\mathrm{K}}$, calculated 
using the retention times of n-alkanes and adopting the definition of Van den Dool and Kratz [18].

\section{DISCUSSION}

All 40 essential oil samples that produced similar GC profiles were characterized by a very high total percentage of ethers (i.e. 1,8-cineole, methyl eugenol, eugenol, methyl isoeugenol and elemicin): $46.5 \%$ on average. A total of 71 peaks were considered. Among them, 60 compounds were identified. The total percentage attributable to identified compounds was $98.7 \%$. Table 3 reports the results of the composition of the four samples from Hammamet.

1,8-Cineole (see Fig. 1) was the main constituent of the oils. The mean value obtained from four samples during the space of a year for each site, ranged from 25.6\% (Ain Essobeh) to $33.0 \%$ (Ain Elkhassa); the overall average was $29.6 \pm 4.3 \%$. $\alpha$-Terpinyl acetate and methyl eugenol exchange with each other as the second and third main constituent. Also the per cent areas for these two constituents are similar; indeed, the mean values calculated over the 40 samples are $13.6 \pm 3.7$ and $13.5 \pm 1.9 \%$ for methyl eugenol and $\alpha$-terpinyl acetate, respectively. Other compounds present in considerable amount in the totality of the samples are: sabinene (mean value $5.6 \pm 1.3 \%$ ), linalool $(4.7 \pm 2.3 \%)$, $\alpha$-pinene $(4.1 \pm 0.9 \%)$ and terpin-4-ol $(2.6 \pm 0.9 \%)$.

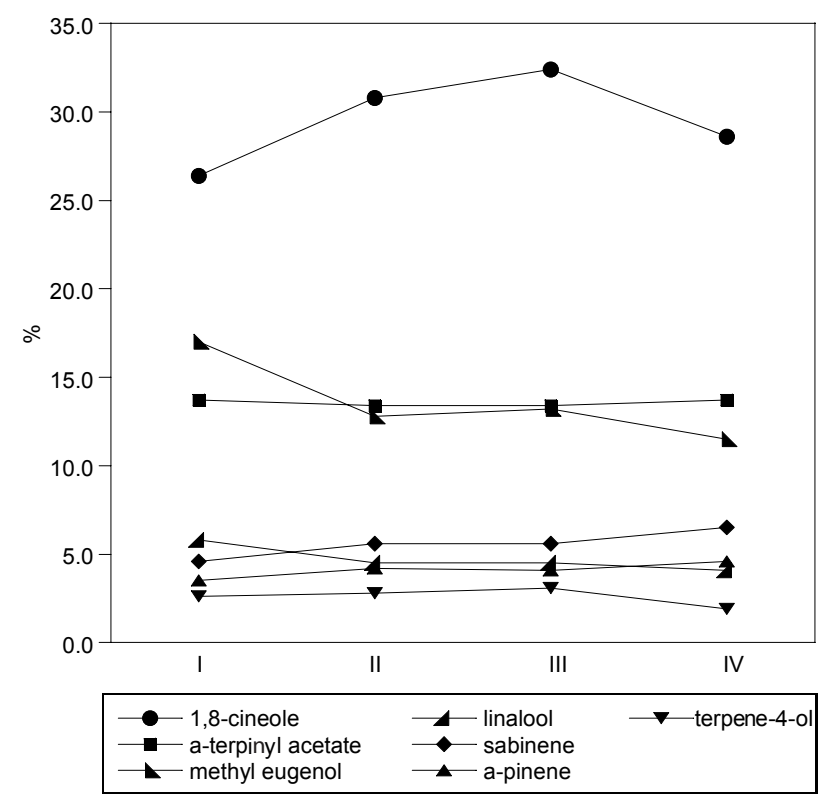

Fig. (1). Percentages (averages of 10 sites of collection) for principal constituents of essential oil at different vegetative stage: I, production of seeds; II, dormancy; III, flowering; IV, vegetative activity.

Each constituent of the oils was considered belonging to a given class: i.e. monoterpenes, sesquiterpenes and phenylpropanoids, both hydrocarbon are oxygenated. Attributions are reported in Table 1. All essential oils considered were characterized by a clear predominance of oxygenated compounds chiefly monoterpenes then phenylpropanoids and sesquiterpenes. The concentration of this class (and specially of oxygenated phenylpropanoids) generally decreases during the period October - July; the values are in the range $67.5 \%$ - $86.1 \%$. As a consequence, methyl eugenol, the more represented among phenylpropanoids, follows the same trend, and its higher concentration is found always in October. In general, April (flowering period) is the month in which is higher in the production of 1,8-cineole ( 7 cases out of 10; see Fig. 2).

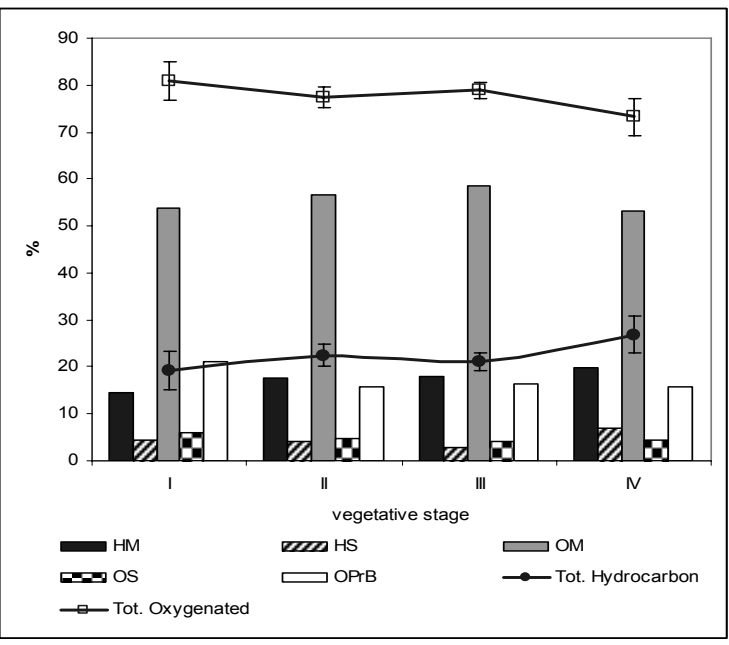

Fig. (2). Percentages (averages of 10 sites of collection) for principal classes characterizing the oil at different vegetative stage: I, production of seeds; II, dormancy; III, flowering; IV, vegetative activity.

Exceptions are seen in samples from Ain Elkhassa, Ain Essobeh and Sajnane. In the same period considered before, the total amount of hydrocarbon compounds increase. This behavior is showed quite clearly by sabinene and $\alpha$-pinene.

The yields in essential oil range between 0.65 and $2.2 \%$ by weight. The higher mean value was obtained utilizing the leaves from Sousse, and the lower value was from samples coming from La Marsa. There was only one exception (Ain Esnoussi 2) to the above, when the period which was higher in the production of essential oil was July, the vegetative period (Table 2). Similar results are reported in Riaz et al. [12]; they found that the essential oil recovery increased in early June, reached a maximum in late July, and constantly decreased thereafter. On the other hand, Putievsky et al. [11] found that the content of essential oil in fresh leaves from cultivated trees of $L$. nobilis reached the highest level in Autumn, while the lowest level was observed in late Spring.

We attempted unsuccessfully to verify if the presence of some compounds could be utilized to distinguish between samples of different origin. We found some peculiar characteristics. For example, spathulenol was present in relatively high amounts $(2.2-3.1 \%)$ in all samples coming from Ain Essobeh, while in the remaining oils, this value did not exceed $1.7 \%$. The samples from Rades were, on average, the richest in both in $\alpha$-terpinyl acetate $(15.3 \%)$ and in methyl eugenol $(17.3 \%)$.

The analysis revealed an inverse correlation between methyl eugenol and 1,8-cineole, but this fact does not imply that a common reaction pathway or a direct chain of reac- 
tions involving these two compounds is possible. Indeed, is well known [19] that the biosynthetic pathways for terpenoids and phenylpropanoids are different.

In conclusion, among the samples of laurel leaf oil examined. We can say that a seasonal variation both in yield and composition has been revealed, whereas geographical variability is not pronounced, and no chemotypes have been observed

\section{REFERENCES}

[1] Castroviejo, S.; Lainz, M.; Lopez Gonzalez, G.; Montserrat, P.; Munoz Garmendia, F.; Paiva, J.; Vilmlar, L. Flora Iberica. Plantas Vasculares de la Peninsula Ibérica et Islas Baleares. - lycopodiaceae-papaveraceae, Real Jardín Botánico, ed. C.S.I.C., Madrid, 1986, Vol. 1, pp. 198-200.

[2] Matsuda, H.; Shimoda, H.; Ninomiya, K.; Yoshikawa, M. Inhibition mechanism of costunolide, a sesquiterpene lactone isolated from Laurus nobilis, on blood-ethanol elevation in rats: involvement of inhibition of gastric emptying and increase in gastric juice secretion. Alcohol. Alcohol., 2002, 37, 121-127.

[3] Sayyah, M.; Vaizadeh, J.; Kamalinejad, M. Anticonvulsant activity of the leaf essential oil of Laurus nobilis against pentylenetetrazole and maximal electroshock-induced seizures. Phytomedicine, 2002, 9(3), 212-216.

[4] Simic, M.; Kundakovic, T. K.; Kovacevi, N. Preliminary assay on the antioxidantive activity of Laurus nobilis extracts. Fitoterapia, 2003, 74(6), 613-616.

[5] Kilic, A.; Altunas, E. Wood and bark volatile compounds of Laurus nobilis L. Holz als Roh-und Werkstoff, 2006, 64, 317-320.

[6] Fang, F.; Sang, S.; Chen, K.Y.; Gosslau, A.; Ho, C.T.; Rosen, R.T. Isolation and identification of cytotoxic compounds from Bay leaf (Laurus nobilis). Food Chem., 2005, 93, 497-501.

[7] Dadalioglu, I.; Evrendilek, G.U. Chemical compositions and antibacterial effects of essential oils of Turkish oregano (Origanum minutiflorum), bay laurel (Laurus nobilis), Spanish lavender (Lavandula stoechas L.) and fennel (Foeniculum vulgare) on common foodborne pathogens. J. Agric. Food Chem., 2004, 52, 8255-8260.
[8] Caredda, A.; Marongiu, B.; Porcedda, S.; Soro, C. Supercritical carbon dioxide extraction and characterization of Laurus nobilis essential oil. J. Agric. Food Chem., 2002, 50, 1492-1496.

[9] Marzouki, H.; Khaldi, A.; Chamli, R.; Bouzid, S.; Piras, A.; Falconieri, D.; Marongiu, B. Biological activity evaluation of the oils from laurus nobilis of Tunisia and Algeria extracted by supercritical carbon dioxide. Nat. Prod. Res., 2009, 23, 230-237.

[10] Marzouki, H.; Piras, A.; Bel Haj Salah, K.; Medini, H.; Pivetta, T.; Bouzid, S.; Marongiu, B.; Falconieri, D. Essential oil composition and variability of Laurus nobilis L. growing in Tunisia, comparison and chemometric investigation of different plant organs. Natural Product Res., 2009, 23, 343-354.

[11] Putievsky, E.; Ravid, U.; Snir, N.; Sanderovich, D. The essential oils from cultivated bay laurel. Israel J. Bot., 1984, 33, 47-52.

[12] Riaz, M.; Ashraf, C.M.; Chaudhary, F.M.; Studies of the essential oil of the Pakistani Laurus nobilis LINN in different seasons. Pak. J. Sci. Indust. Res., 1989, 32, 33-35.

[13] Greche, H.; Alaoui, M.I.; Ajjaji, N.; Zrira, S.; Bellanger, A.; Benjilani, B. Rendement et composition chimique de l'huile essentielle de Tanacetum аппиит L. Plante aromatiques et médicinales et leurs huiles essentielles. Proceedings of the Congrés international organisé par l'institut Agronomique et Vétérinaire Hassan II; Maroc, R. Ed. Actes ed., 1997, pp. 169-176.

[14] Van Vuuren, S.F.; Viljoen, A.M.; Özek, T.; Demirci, B.; Başer, K.H.C.; Seasonal and geographical variation of Heteropyxis natalensis essential oil and the effect thereof on the antimicrobial activity. South Afr. J. Bot., 2007, 73, 441-448.

[15] Simard, S.; Hachey, J.M.; Colin, G.J. The variation of the essential oil composition with the extraction process, the case of Thuja occidentalis L. and Abies balsamea (L.) Mill. J. Wood Chem. Technol., 1988, 8(4), 561-573.

[16] Adams, RP. Identification of Essential Oil Components by Gas Chromatography/Mass Spectroscopy. Allured Publ. Corp.: Carol Stream, IL (USA), 1995

[17] NIST/EPA/NIH Mass Spectral Library, National Institute of Standard and Technology, Gaithersburg, 2002.

[18] Van den Dool, H.; Kratz, P.D. A generalization of the retention index system including linear temperature programmed gas-liquid partition chromatography. J. Chromatogr., 1963, 11, 463-471.

[19] Dewick, P.M. Medicinal Natural Products, a Biosynthetic Approch. Wiley: New York (USA), 1997.

(C) Marzouki et al.; Licensee Bentham Open.

This is an open access article licensed under the terms of the Creative Commons Attribution Non-Commercial License (http://creativecommons.org/licenses/by-nc/3.0/) which permits unrestricted, non-commercial use, distribution and reproduction in any medium, provided the work is properly cited. 